\title{
SEROLOGY FOR LEPTOSPIRA SP. IN CATTLE OF THE STATE OF PARAÍBA, BRAZIL
}

\author{
A.P. Lage ${ }^{1}$, R. de M .H. Leite ${ }^{1,2}$, J A. Thompson³, D .A. Bandeira², \\ G .P. Herrmann ${ }^{4}$, É.C. M oreira ${ }^{1}$, V.S.P. G onçalves ${ }^{5}$
}

¿UniversidadeFederal deMinas Gerais, Escola deV eterinária, Departamento deM edicinaV VeterináriaPreventiva, Núcleo dePesquisaem SaúdeA nimal, Laboratório deBacteriologiaA plicada, CP 567, CEP 30123-970, Belo Horizonte, MG, Brasil. E-mail: alage@vet.ufmg.br

\begin{abstract}
A survey wasconducted to estimatethefrequency ofL eptospira sp. infection in cattlein theState of Paraíba, Brazil. A random sample of 6 municipalities was chosen from each of 3 ecoregions of thestate: theA greste/ Litoral, theCariri/ Curimatau and theSertão. These18municipalitieswere broken down into quadrants and one property was selected at random from each quadrant. Random samples were collected from at least eight animals at each property, in four-age categories, summing at least 32 animals per property. All municipalities that wereincluded in the study (100\%) and $87.75 \%$ of theproperti eshad at leastonepositivesamplefor oneof the 15 different Leptospira sp. serovars (16 strains) studied. From 2,343 samples, 759 showed positive reaction to, at least, one of the 16 strains tested. Four hundred and seventy animal s were positiveto multiple strains. The serovar Hardjo, of the Sejroe serogroup, was the most frequent and accounted for $16.05 \%$ (95\% Cl $-12.69 \%$ to $19.41 \%$ ) of the positive results (376 positive reactions). There were differencesin thefrequency of positiveresultsaccording to thetwo strainsof serovar $\mathrm{H}$ ardjo used: strain Norma (15.62\% - 95\% Cl - 12.38\% to 18.86\%), isolated in Brazil, and reference strain Hardjoprajitino (2.43\%- $95 \% \mathrm{Cl}-1.12 \%$ to $3.75 \%)$. Theremaining serovars tested had frequencies lower than 2.8\%. Results obtained in thepresentstudy confirmed thatL eptospira interrogansserovar $\mathrm{H}$ ardjo is widely spread in the State of Paraíba, Brazil.
\end{abstract}

KEY WORDS: Leptospirosis, L. interrogans serovar Hardjo, epidemiology, cattle, Paraíba, Brazil.

RESUMO

SOROLOGIA PARA LEPTOSPIRA SP. EM BOVINOSDO ESTADO DA PARAÍBA, BRASIL. Foi realizadaa estimativa defreqüência deinfecção porL eptospira sp. em bovinosdo Estado da Paraíba, Brasil. Seis municípios foram escolhidos ao acaso em cada uma das 3 ecorregiões do Estado: Agreste/ Litoral, Cariri/ Curimatau eSertão. Estes 18municípiosforam divididosem quadrantes e uma propriedade foi selecionada por quadrante. As amostras de sangue foram coletadas aleatoriamente de, pelo menos, 32 animais por propriedade. Todos os municípios incluídos no estudo (100\%) e87,75\% das propriedades apresentaram no mínimo uma amostra positivapara pelo menos uma das 15 diferentes sorovariedades de Leptospira sp. (16 amostras) testadas. Dos 2.343 animais examinados, 759 reagiram positivamente para pelo menos uma das 16 amostras de Leptospira sp. testadas. Quatrocentos e setenta animais reagiram positivamente para múltiplas amostras. A sorovariedade $\mathrm{H}$ ardjo, do sorogrupo Sejroe, foi a mais freqüente com $16,05 \%$ (95\% IC - $12,69 \%$ a $19,41 \%$ ) dos resultados positivos (376 reações positivas). Houve diferenças na freqüência dos resultados positivos para as amostras da sorovariedade $\mathrm{H}$ ardjo testadas: amostra Norma (15,62\% - 95\% IC - 12,38\% a 18,86\%), isolada no Brasil, e a amostra de referência Hardjoprajitino (2,43\% - 95\% IC - 1,12\% a 3,75\%). As demais sorovariedades apresentaram freqüências inferiores a 2,8\%. Os resultados obtidos no presenteestudo confirmam quel eptospira inter rogans serovar Hardjo é amplamente distribuída no Estado da Paraíba, Brasil.

PALAVRAS-CHAVE: Leptospirose, L . interrogansserovar Hardjo, epidemiologia, bovinos, Paraíba, Brasil.

\footnotetext{
²Empresa Estadual de Pesquisa Agropecuária da Paraíba, João Pessoa, PB, Brasil

${ }^{3}$ Texas A\&M University, Collegeof Veterinary M edicine, Department of LargeA nimal M edicineand Surgery, College Station, USA.

${ }^{4}$ Universidade Federal de Santa Maria, Departamento de Microbiologia e Parasitologia, Santa Maria, RS, Brasil.

5Universidade de Brasília, Faculdade de A gronomia e M edicina Veterinária, Brasília, DF, Brasil.
} 


\section{INTRODUCTION}

Leptospirosis is caused by one of the seven pathogenicspecies of $L$ eptospira, which aredistributed in 25serogroups, divided into morethan 190serovars defined by antigenic affinity (LEVETT, 2001). Several serovars of Leptospira sp. have been isolated from cattle in Brazil, however, the serovar Hardjo has recently been found to be the most frequent serologically and the one that causes greater impact in the reproductive efficiency of cattle herds (VAsconcellos et al., 1997). Infected animals can develop either an acuteor chronicform of thedisease. Infected herds can present low reproductive performance, temporary infertility, abortions, fetal mummifications and birth of weak calves, mastitis and reduced milk production (ELLIS, 1984, PRESCOTT; ZUERNER, 1993). All those manifestations can lead to major economical losses in Brazil due to its wide distribution (NAsConcelLos et al., 1997), as al ready reported in the State of Paraíba (LeITE et al., 2000).

The Brazilian State of Paraíba is the most eastern point of the A mericas. Paraíba holds a population of $3,305,616$ inhabitants, coversan area of $56,584.6 \mathrm{~km}^{2}$, contains 223 municipalities and is located in a tropical climate. Cattle production is one of the major agricultural activities, with atotal herd sizeof 1,327,826 animals (IBGE, 1998). Cattle production is mostly extensive, on semi arid soils with poor vegetation and low rain indices. A ccording to the ComitêdePlanejamento A gropecuário do Estado da Paraíba, thereare threetypes of cattleregionsin theStatein linewith the threeecological areas: theAgreste/ Litoral region, the Cariri/ Curimatau region and the Sertão region.
The objective of the present study was to estimate theoccurrence of Leptospirasp. infecton in commercial cattle herds in the State of Paraíba, Brazil.

\section{MATERIAL AND METHODS}

\section{Sampling}

A sampleframewas developed containing alist of potential participants from both dairy and beef production properties (farm). To be eligible for inclusion in the study the property would have to hold at least 50 animals. Eligible properties were required to have information concerning health status, reproduction and management. Therefore, thesampleframewas restricted to commercial cattle herds. Small-scale subsistence herders were not targeted by the present survey. Property managers were pre-screened for their willingness to participate. A random sample of six municipalities was chosen from each of three ecoregions (cattle breeding regions): the Agreste/ Litoral region (1), the Cariri/ Curimatau region (2) and the Sertão region (3) (Fig. 1). Six municipal ities wererandomly selected from each ecoregion: A lagoinha, Bananeiras, Fagundes, J oão Pessoa, Tacimaand U mbuzeiro from ecoregion 1; Boqueirão, Campina Grande, Gurjão, Monteiro, Serra Branca and Soledade from ecoregion 2; Concei ção, Patos, Piancó, Pombal, Riacho dos Cavalos and Souza from ecoregion 3. These18municipalitiesweredivided in quadrants and oneproperty wasselected at random fromeach quadrant.

Table 1 - Serovars of Leptospira sp. used in the Microscopic Agglutination Test (MAT) for testing cattle from the State of Paraíba, Brazil.

\begin{tabular}{lll}
\hline Serogroups & Serovar & Strain \\
\hline Australis & Australis & Ballico \\
& Jratislava & Jez Batislava \\
Autumnalis & Autumnalis & Akiyamy A \\
Ballum & Castelonis & Castellon 3 \\
Bataviae & Bataviae & Swart \\
Canicola & Canicola & Hond Utrecht IV \\
Grippotyphosa & Grippotyphosa & Moskva V \\
Hebdomadis & Hebdomadis & Hebdomadis \\
Icterohaemorrhagiae & Icterohaemorrhagiae & RGA \\
Mini & Szwajizak & Szwajizak \\
Pomona & Pomona & Pomona \\
Pyrogenes & Pyrogenes & Salinem \\
Sejroe & Hardjo & Hardjoprajitno \\
& & Norma \\
Tarassovi & Wolffi & 3705 \\
\hline
\end{tabular}




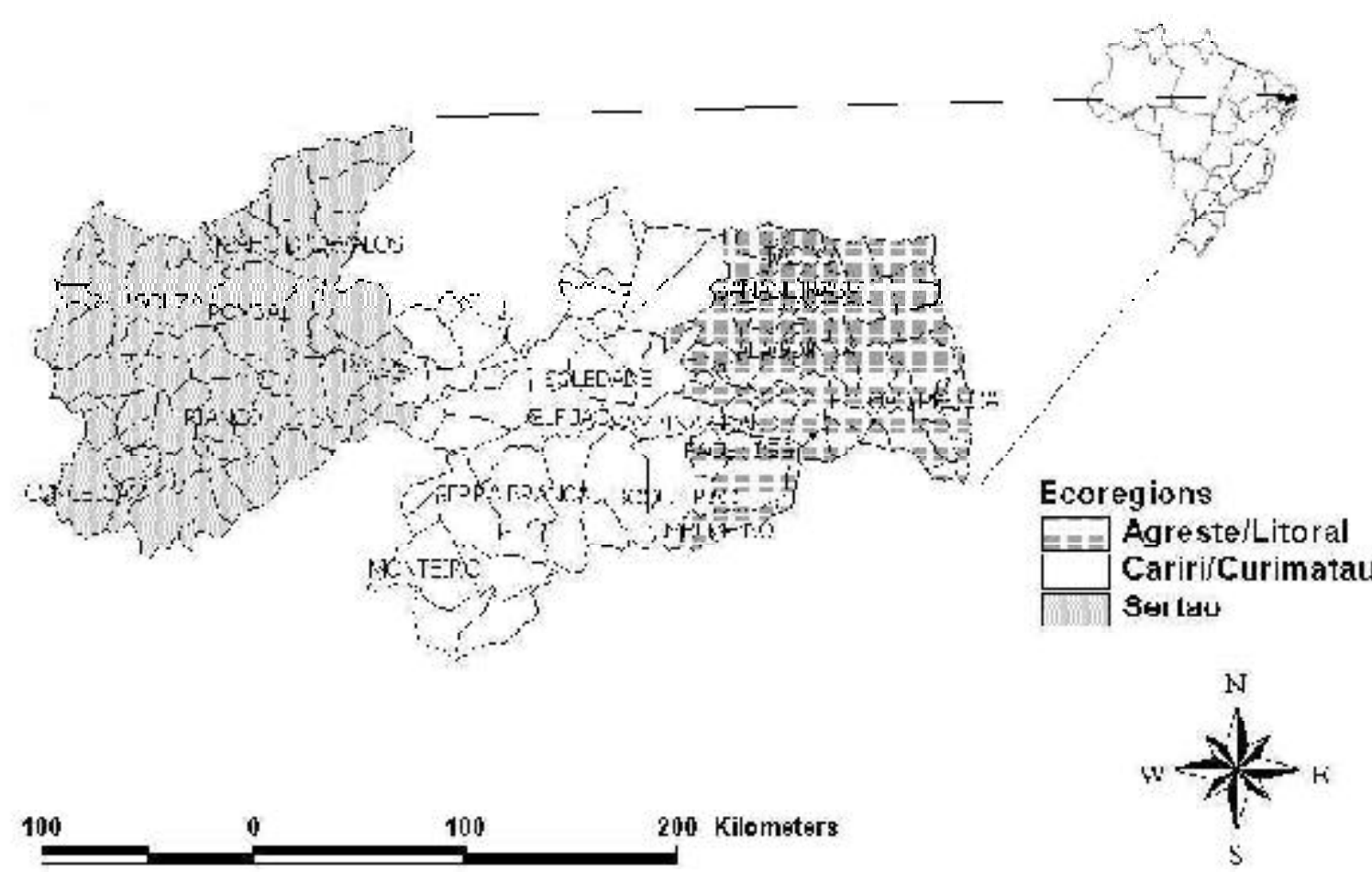

Fig. 1 - Ecoregions and Municipalities sampled for the study in the State of Paraíba, Brazil.

\section{Animals}

Blood samples, totaling at least 32 animals per property, wererandomly collected fromat leasteight animals of each property of the following age categories: (1) 0to 6 months, (2) 7 to 18 months, (3) 19 to 30 months and (4) more than 30 months From march to September of 2000 serum samples were collected through jugular venopunction and stored at minus 20ㅇ C until tested.

\section{Serological testing}

A battery of 15 different serovars (16 strains) of Leptospira sp. (Table 1) was used as antigen. Each strain was harvested from EMJH medium, after a seven-day incubation period at $27^{\circ} \mathrm{C}$, with approximately $1-2 \times 10^{8}$ bacteria/ $\mathrm{mL}$, free of contaminants and of auto-aggl utination. Thechoice of the serovars to be used as antigens was made based on reports of the most frequent leptospiral serovars serologically found in Brazil. Serum samples were tested by the Microscopic A gglutination Technique(MAT) (CoLE et al., 1973; OIE, 2000). Reactions were read directly on microplate (Nunc, Denmark) with a microscope equipped with a dry condenser and a dark field, long distance objective (Axiolab, Carl Zeiss, Germany). N egative and positive sera and culture control standards wererun in each assay. Sera were screened at 1:100 dilution and diluted on atwo-fold basis up to obtain the final titer. Sera presenting $50 \%$ or more agglutinated Leptospira sp. per microscopicfield atagiven dilution wereconsidered positive.

Microscopic agglutination test is the method recommended by OIE for the diagnosis of leptospirosis in animals. This test detects predominantly IgM and helps to identify the infecting serovar, which is essential for the establishment of a vaccination program (FAINE etal., 1999, OIE, 2000). Vaccination, like infection, can stimulate specific anti-Leptospira sp. IgM shortly after use (Godda r et al., 1991). In the present study, only a small percentage of herds vaccinated the animals against leptospirosis (LEITE et al., 2004) and none of these herds were sampled less than three month after vaccination.

In the present study, only in a small percentage of herds, the animals were vaccinated against leptospirosis (LEITE et al., 2004) and none of these herds were sampled before three month after vaccination. Therefore, the results obtained werenot influenced by vaccine use.

\section{Statistics}

Frequencies, confidence intervals $(\mathrm{Cl})$, design effects and intracluster correlation coefficients were calculated according to BENNETT et al. (1991). 


\section{RESULTS}

All municipalitiesthat wereincluded in thisstudy (100\%) and $87.75 \%$ of the properties had at least one positive sample for one of the 15 different Leptospira sp. serovarsstudied (Table2). Outof the2,343samples, 759 animals showed positivereactionto one of the 16 strains tested. Four hundred and seventy animals tested positively for multiplestrains.

Table2-Seropreval enceof L eptospirasp. serovarsin 2,343 cattle in the State of Paraíba, Brazil.

\begin{tabular}{lrrrr}
\hline Serovar & Positive & $\%$ & \multicolumn{2}{c}{$95 \% \mathrm{Cl}^{1}$} \\
\cline { 3 - 5 } & & & min & max \\
\hline Australis & 5 & 0.21 & 0.00 & 0.43 \\
Autumnal is & 34 & 1.45 & 0.46 & 2.44 \\
Bataviae & 21 & 0.90 & 0.53 & 1.26 \\
Bratislava & 54 & 2.30 & 1.40 & 3.21 \\
Canicola & 7 & 0.30 & 0.00 & 0.66 \\
Castelonis & 16 & 0.68 & 0.23 & 1.13 \\
Grippothyphosa & 3 & 0.13 & 0.00 & 0.27 \\
Hardjo & 376 & 16.05 & 12.69 & 19.41 \\
strain Norma & 366 & 15.62 & 12.38 & 18.86 \\
strain Hardjoprajitino & 57 & 2.43 & 1.12 & 3.75 \\
Hebdomadis & 31 & 1.32 & 0.60 & 2.05 \\
Icterohaemoragiae & 5 & 0.21 & 0.00 & 0.43 \\
Pomona & 10 & 0.43 & 0.04 & 0.81 \\
Pyrogenes & 13 & 0.55 & 0.17 & 0.94 \\
Szwajizak & 65 & 2.77 & 1.19 & 4.36 \\
Tarassovi & 38 & 1.62 & 0.72 & 2.52 \\
Wolffi & 34 & 1.45 & 0.71 & 2.19 \\
\hline
\end{tabular}

$1-95 \% \mathrm{Cl}-95 \%$ confidence interval of the mean

Theserovar $\mathrm{H}$ ardjo, of theSerjoeserogroup, was themost frequent and accounted for $16.05 \%(95 \% \mathrm{Cl}$ -12.69\%to 19.41\%) of thepositiveresults(376positive reactions) obtained by summing positives for strain N orma (366) with positivesfor strain Hardjoprajitino (57) and positives for both (47). The serovar Hardjo Norma strain contributed to $15.62 \%$ of the reactions $(95 \% \mathrm{Cl}-12.38 \%$ to $18.86 \%)$ and the referencestrain Hardjoprajitino to $2.43 \%(95 \% \mathrm{Cl}-1.12 \%$ to $3.75 \%)$. Forty-seven animals tested positive for both serovar Hardjo strains, Norma and Hardjoprajitino, but all presented higher agglutinating titers for $\mathrm{N}$ orma strain.

Lower frequencies of infection were found for serovars Szwajizak (2.77\%), Brastilava (2.30\%), Tarassovi (1.62\%), Wolffi (1.45\%), Autumnalis (1.45\%) and Hebdomadis (1.32\%). The remaining serovars tested had frequencies of less than $1.0 \%$ (Table 2).

\section{DISCUSSION}

Some studies carried out in Brazil estimated the prevalenceof Leptospirasp. infection intargeted higherrisk populations (MoreIRA et al., 1979; Doria et al., 1980; Madruga et al., 1980; Ribeiro et al., 1988; LILENBAUM etal., 1995; VAsConcELLosetal., 1997). Inthe most recent ones, LILENBAUM et al. (1995) and VASCONCELLos etal. (1997), theserovar Hardjo was the most prevalent followed by serovar Wolffi.

Although it is difficult to compare those studies with thecurrent one because of differences in sample design and Leptospira sp. serovars tested, this study also found serovar $\mathrm{H}$ ardjo to bethemost frequentand widely disseminated in cattle in the State of Paraíba, Brazil. Conversely, there was a lower frequency of many other serovars such as Szwajizak, Brastilava, Tarassovi, Wolffi, Autumnalis and Hebdomadis (Table 2) already detected at lower rates in other studies in brazilian cattle (GuIDA et al., 1959; SANTA RosA etal., 1961; M oreira etal., 1979; GIORG etal., 1981, MOREIRA, 1994). These results confirm the status of cattle as the usual reservoir for serovar Hardjo and reinforce that its high frequency may interfere with cattle production (PrescotT et al., 1993; FAINe et al., 1999; LeITE et al., 2000).

Using thesamesampling frameof thisstudy, LEITE et al. (2004) reported that $10.1 \%$ to $19 \%$ of the herds experienced reproductive problems as abortions, stillbirths, and weak calves. Although these signs could berelated to leptospirosis, this diseasewas not known by herd owners and workers in Paraíba and only $8.7 \%$ of thestudied herdswerevaccinated against leptospirosis (LEITE at al., 2004). Recognition of the diseaseisthefirstand oneof themostimportantsteps in a control program. This absence of disease recognition, which precludes theadoption of control strategies in affected herds, is in sharp contrast to the leptospirosis $16 \%$ frequency found in the present study and the of disease outbreaks detection ,with reproductiveand bloody mastitissignsin theParaíba State (LEITE et al., 2000). Hence, control programs for leptospirosis in Paraíba must be preceded by educational programs. Hence, in Paraíba, thecontrol of leptospirosis, must bepreceded by an educational program.

Results for the two serovar Hardjo strains used were markedly different, with strain N ormayielding most of positive animals. Diagnostic differences between $\mathrm{H}$ ardjo strains N orma and Hardjoprajitino, thereferencestrain, wereal ready observed, withlesser or greater intensity, in other cattle and sheep populationsfromother statesin Brazil (MOREIRA, 1994, HerRmann et al., 2004). Strain N orma was isolated in theStateof M inasGerais, Brazil and wasidentified by monoclonal antibodies and PCR as L. interrogans 
serovar Hardjo genotype Hardjoprajitino (Korver personal communication ${ }^{1}$ ) (MoreIRA, 1994). The differencesfound wereprobably duetothelow passage and origin of strain N orma. Being isolated in 1991, strain Norma has a smaller number of "in vitro" passagesthan strain Hardjoprajitinothat wasisolated in 1938 from a man in Sumatra (Wolff, 1969). Furthermore, theantigenicrelationship betweenstrain Norma and L. interrogans serovar Hardjo infecting cattle in Brazil is probably closer than that of strain Hardjoprajitino, because it was isolated in the same country and from cattle (MOREIRA, 1994). FontANALs $\mathrm{t}$ al. (2001) studying different isolated of $L$. inter rogans serovar Pomona from cattle found similar results. FONTANALS et al. (2001) found similar results studying different cattle isolates of $L$. interrogans serovar Pomona. These results suggest an increase in sensitivity of diagnosis of infected cattleby the use of a local isolated strain of serovar Hardjo.

Risk analysis on the spatial and age distribution has al ready been performed in thesameset of datafor serovar Hadjo infection (THOMPSON et al., 2006). The effect of ecoregion was observed; higher prevalence was reported in the A greste/ Litoral region, which is closer to the coast, showing higher humidity than the other regions studied (SEMARH/ LMRS-PB, 2002). An age effect was also observed. A nimals younger than seven months havealower prevalenceratethan older ones. Theprevalence rateincreases with agein animalsolder than 6 month, whichiscompatiblewith a greater time of exposure in older animals.

In conclusion, the present survey confirms that serovar Hardjo is the most frequent in cattle in the State of Paraíba, Brazil, followed by other serovars withlowerfrequencies, namely Szwajizak, Brastilava, Tarassovi, Wolffi, Autumnalis and Hebdomadis. Likewise, resultsstrengthen theuseof serovar Hardjo strain N orma as the most sensitivefor the diagnostic of Leptospira sp. infection in cattle in Brazil.

\section{ACKN OWLEDGEMENTS}

RMHL, ECM, and APL are indebted to Consel ho N acional deDesenvolvimento Científico eTecnológico - CN Pqfor thefellowships. Thisstudy wassponsored by Secretaria de A gricultura do Estado da Paraíba (SAIA) and Fundação deEstudo ePesquisa em M edicina Veterinária eZootecnia - FEP/ MVZ Coordenação Preventiva. The farmers of the State of Paraíba, Brazil, which participated in this study, are acknowledged.
REFERENCES

Bennett, S.; Woods, T.; Lyanage, W.M.; Silth, D.L. A simplified general method for cluster surveys of health in developing countries. W orld $\mathrm{H}$ ealth Statistics Quaterly, v.44, p.98-106, 1991.

Cole, J.R.; Sulzer, C.R.; Pursell, A.R. Improved Microtecnique for the leptospiral microscopic agglutination test. A pplied M icrobiology, v.25, p.976980, 1973.

Doria, J.D.; Viegas, S.A.R.A.; Viegas, E.A., SANTOS, N.M., VIRGENS, N.C. Estudo sorológico sobrealeptospirose em bovinos no Estado da Bahia. A rquivos da Escola de M edicina V eterinária da U niversidade Federal da Bahia, v.5, p.159-167, 1980.

ELLIS, W.A. Bovineleptospirosisinthetropics: Prevalence, pathogenesis and control. Preventive $V$ eterinary M edicine, v.2, p.411-421, 1984.

Ellis, W.A. Leptospirosis. In: Straw, B.E., D'allaire, S., Mengeling, W.L., TAYLOR, D.J. (Eds.). D iseases of swine. 8th ed. Oxford: Blackwell Scientific, 1999. p.483-493.

Faine, S.; Adler, B.; Bolin, C.; Perolat, P. Leptospira and leptospirosis. 2nd ed. Melbourne: Medi. Sci., 1999. 272p.

Fontanals,A.; Lorenete,P.;Samaritano, L.; Mundo, S. Leptospira interrogans serovar pomona: deteccíon de diferencias antigénicas entre tres aisl amientos regionales de bovinos y una cepa de referencia. R evista A rgententina de M icrobiologia, v.33, p.108-112, 2001.

Giorgi, W.; Teruya, J.M.; Sllva, A.S.; Genovez, M.E. Leptospirose: Resultadosdas soroaglutinações real izadas no Instituto Biológico deSão Paulo duranteos anos de 1974/ 1980. Biológico, São Paulo, v.47, p.299309, 1981.

Guida, V.O.; Santa Rosa, C.A.; Dápice, M.O. Pesquisa de aglutininas anti-leptospira no soro de bovinos do Estado deSão Paulo.A rquivos do I nstituto Biológico, São Paulo, v.26, p.109-118, 1959.

Goddard, R.D.; LufF, P.R.; ThORNTON , D.H. The serological response of calves to Leptospira interrogans serovar hardjo vaccines and infection as measured by the microscopicagglutination testand anti-IgM and antiIgG enzyme-linked immunosorbent assay. V eterinary M icrobiology, v. 26, p. 191-201, 1991.

Herrmann, G.P., L age, A.P., M oreira, E.C., H addad, J. P. A., Resende, J. R., Rodrigues, R. O., Leite, R. C. Soroprevalência de aglutininas anti-Leptospira spp em ovinos nas mesorregiões Sudeste e Sudoeste do Estado Rio Grande do Sul, Brasil.Ciência Rural, v. 34, p. 443 - 448, 2001.

Instituto Brasileiro de Geografia e Estatistica. Censo Agropecuário 1996. Disponível em: Łttp:/ / www. sidra.ibge.gov.br/ cgr-bm/ prtabr>. A cesso em: 25 out. 1998.

Leite, R.M.H.; Leite, R.C.;BAndeiRA, D.A.; LAge, A.P. Surtode LeptospiroseemrebanhosbovinosnoEstadodaParaíba. Ciência V eterinaria nos Tropicos, v.3, p.144-149, 2000.

\footnotetext{
${ }^{1} \mathrm{H}$ ans Korver - Royal Tropical Institut (KIT) - 39 H eibergdreef - 1105 AZ A msterdam - The Nederlands
} 
Leite, R.M.H.; Lage, A.P.; Jayme, V.S.; Modena, C.M. Perfil produtivo-sanitário de propriedades produtoras de bovinos do Estado da Paraíba, Brasil, 2000. Ciencia A nimal Brasileira, v.5, p.199-209, 2004.

LeVett, P.N. Leptospirosis. Clinical M icrobiology Reviews, v.14, p.296-326, 2001.

Lilenbaum, W.; Santos, M.R.C.; Barbosa, A. V.Leptospirose em reprodução animal :II - Bovinos do Estado do Rio deJaneiro, Brasil. Revista Brasileira deCiênciaV eterinária, v.2, p.1-6, 1995.

Madruga, C.R.; Aycardi, E.; Putt, N. Freqüência de aglutininas antileptospiras em bovinosde corte da região sul de cerrado no Estado de Mato Grosso. A rquivos da Escola deV eterinária da U niversidadeF ederal de $M$ inas Gerais, v.32, p.245-249, 1980.

Martin, S.W.; Meek, A.H.; Wlleburg, P. V eterinary epidemiology: principles and methods. Ames: Iowa State University Press, 1987. p.33-35.

Moreira, E.C. A valiação de métodos para erradicação de leptospiroses em bovinos leiteiros. 1994. 94f. Tese (Doutorado em CiênciaA nimal - Área deM edicina Veterinária Preventiva e Epidemiologia) - Escola deVeterinária da Universidade Federal de Minas Gerais, Belo Horizonte, 1994.

Moreira, E.C.; Slva, J.S.; Viana, F.C.; Santos, W.L.M.; Anselmo, F.P.; LeITE, R.C. Leptospirose bovina I. Aglutininas anti-leptospirasemsorossanguíneosde bovinos de M inas Gerais. A rquivos da Escola de $V$ eterinária da U niversidade Federal de M inas Gerais, v.31, p.375-388, 1979.

Office International des Epizooties. M anual of Standards for D iagnóstic Test and V accines. 4th ed. Paris: OIE, 2000. Leptospirosis, p.198-217.

Paraíba.SecretariaExtraordináriado Meio Ambiente, dos Recursos Hídricos e Minerais/ Laboratório de Metereologia. Recursos H ídricos eSen soriamento R emoto da Paraíba. Disponível em: 丸ttp:/ / www.Imrssemarh.ufpb.br/ meteoro/ prec ano.html >. Acesso em: 3 jan. 2002.
Prescott, J.F.; Zuerner, R.L. Leptospira. In: Gyles, C.L.; THOen, C.O.Pathogenesis of bacterial infectionsin animals. 2nd ed. Ames: Iowa State University Press, 1993. p.287-296.

Radostits, O.M.; Bood, D.C.; Gay, C.C. V eterinary $M$ edicine. A textbook of the diseases of catle, sheep, pigs, goats and horses. 7th ed. London: Bailliére Tindall, 1994. $1763 p$.

Ribeiro, S.C.A.; Gouveia, M.A.V.;SILVA, P.L.; Oliveira, P.R.; BARBosa,F.C.; M AmEDE, D.O.Levantamento sorológico emdoissurtosdeleptospirosebovinaemUberlândia, Triângulo Mineiro. A rquivo Brasileiro de Medicina V eterinária e Z ootecnia, v.40, p.415-423, 1988.

Santa Rosa, C.A.; Castro, A.F.P.; Troise, C. Leptospirose bovina; inquérito sorológico na região deCampinas. A rquivos do Instituto Biologico, São Paulo, v.28, p.169173, 1961.

Thompson, J.A.; Leite, R.M.H.; Goncalves, V.S.P.; LeITe, R.C.; Bandeira,D.A.; Herrmann, G.P.;M oreira, E.C.;Prado, P.E.; LoBATo,ZII.P.;B RITo,C.P.T.;L AGE,A.P.Spatial hierarchical variances and age covariances for seroprevalence to Leptospira interrogans serovar Hardjo, BoHV-1 and BVDV for cattleintheStateofParaiba, Brazil.Preventive V eterinary M edicine, v.17, p.290-301, 2006.

Vasconcellos, S.A.; Barbarini, Junior, O.; Umehara, O.; Morais, Z.M.; Cortez, A.; Pinheiro, S.R.; Ferreira, F.; Fávero, A.C.M.; Ferreira Neto, J.S. Leptospirose bovina. níveis de ocorrência e sorotipos predominantes em rebanhos dos Estados de Minas Gerais, São Paulo, Rio de Janeiro, Paraná, Rio Grande do Sul e Mato Grosso do sul. Período de janeiro a abril de 1996. A rquivos do Instituto Biológico, São Paulo, v.64, p.7-15, 1997.

WoLfF, J.W. History of Leptospira hardjo. A merican Journal of $V$ eterinary Research, v.30, p.485, 1969.

Received on 27/ 9/ 06 Accepted on 24/ 8/ 07 